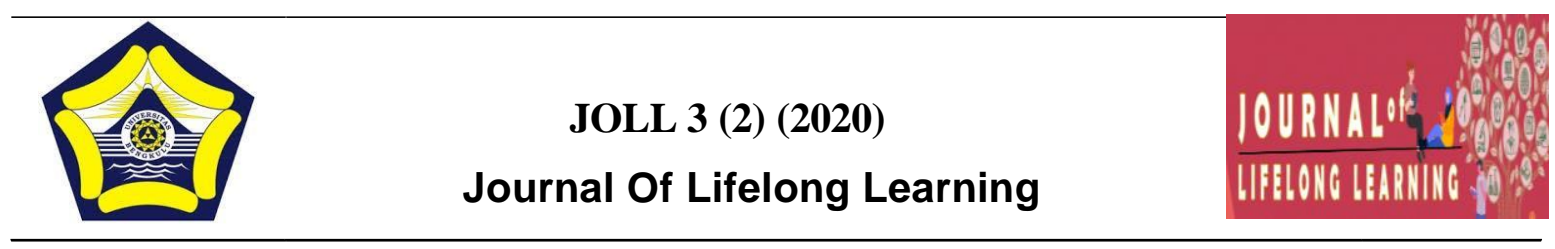

\title{
PROGRAM PEMBERDAYAAN MASYARAKAT \\ BERBASIS MANAJEMEN MASJID
}

Rohman $^{1}$,Agus Zainal Rachmat ${ }^{2}$, Sofino $^{3}$

${ }^{1}$ Rohman, Universitas Bengkulu, Indonesia, rohmanunib@gmail.com

${ }^{2}$ Agus Zainal Rachamt, Universitas Bengkulu, Indonesia, aguszainal@unib.ac.id

${ }^{3}$ Sofinio, Universitas Bengkulu, Indonesia, sofino@unib.ac.id

\begin{abstract}
The purpose of this study is to find out empowerment and community programs in the Baitul Atieq Great Mosque which is a mosque with the Jami mosque's typology. This study refers to indicators of success according to the Decree of the Director General of Islamic Community Guidance in 2014 concerning Standards for Management of Mosque Management. This research is a qualitative case study with four research subjects and data collection techniques using interview, observation and documentation techniques. While data analysis techniques include data reduction, data presentation, and drawing conclusions. Checking the validity of the data using triangulation ranging from time triangulation, subject triangulation and technique triangulation. The results showed that the community empowerment programs carried out at the Baitul Atieq Great Mosque covered the fields of education, da'wah, social and economic, besides the existing programs involved all parties and covered community needs.
\end{abstract}

Keywords: Program, Empowerment, Mosque

C2020 DeptofNonformalEducationUNIB ISSN : 2715-9809

\section{Addresscorrespondence:}

Jl.W.R.Supratman,KandangLimun,MuaraBangkaHulu, KotaBengkulu,Bengkulu38371 


\section{PENDAHULUAN}

Pendidikan nonformal sangat berperan dalam rangka membantu pendidikan formal, menurut Undang-Undang Nomor 20 Tahun 2003 tentang Sistem Pendidikan Nasional Pasal 26 ayat 1 menyatakan bahwa "Pendidikan nonformal diselenggarakan bagi warga masyarakat yang memerlukan layanan pendidikan yang berfungsi sebagai pengganti, penambah dan/atau pelengkap pendidikan formal dalam rangka mendukung pendidikan sepanjang hayat."

Program pendidikan nonformal, lebih lanjut dijelaskan dalam Undang-Undang Nomor 20 Tahun 2003 tentang Sistem Pendidikan Nasional pasal 26 ayat 3, yaitu: Pendidikan nonformal meliputi pendidikan kecakapan hidup, pendidikan anak usia dini, pendidikan kepemudaan, pendidikan pemberdayaan perempuan, pendidikan keaksaraan, pendidikan keterampilan, pelatihan kerja, pendidikan kesetaraan serta pendidikan lain yang ditujukan untuk mengembangkan kemampuan peserta didik.

Dari pengertian diatas, pendidikan nonformal berperan dalam member-dayakan masyarakat, memberikan pelatihanpelatihan, memberantas buta aksara, melakukan pembinaan-pembinaan kepada masyarakat. Menurut Widjaja (2003:169) pemberdayaan masyarakat yaitu: Pemberdayaan masyarakat adalah upaya meningkatkan kemampuan dan potensi yang dimiliki masyarakat, sehingga masyarakat dapat mewujudkan jati diri, harkat dan martabatnya secara maksimal untuk bertahan dan mengembangkan diri secara mandiri baik dibidang ekonomi, sosial, agama dan budaya.

Indonesia sendiri merupakan negara dengan penduduk mayoritas muslim terbesar didunia. Menurut data dari Global Religious Futures A Pew-templeton Project (http://globalreligiousfuture.org) Indonesia merupakan negara dengan masyarakat beragama Islamm terbesar didunia dengan $87,2 \%$ atau 209.120.000 jiwa. Dengan masyarakat muslim yang besar tersebut menjadikan Indonesia memiliki banyak sekali masjid, menurut Ketua Umum Dewan Masjid Indonesia Jusuf Kala (dikutip dari http://www.inews.com ) Masjid Indonesia mencapai 800.000 masjid.

Oleh karena itu, pemberdayaan masyarakat berbasis masjid menjadi salah satu program yang strategis. Menurut Nana Rukaman (2002:08) Menyatakan bahwa "Masjid merupakan wadah yang paling strategis dalam pembinaan dan menggerakkan potensi umat Islam untuk mewujudkan sumber daya manusia yang tangguh dan berkualitas."

Pembinaan masjid atau pemberdayaan jamaah masjid dilakukan oleh pengurus masjid atau takmir masjid yang merupakan kumpulan orang-orang yang mengurusi dan memakmurkan masjid.

Menurut Siswanto (2005:56) pengurus masjid "yaitu organisasi yang mengurus seluruh kegiatan yang ada kaitannya dengan masjid, termasuk dalam pembangunan, merawat maupun memakmurkannya, termasuk usaha-usaha pembinaan terhadap jamaah masjid." 
Keberhasilan pengurus masjid dalam memakmurkan masjid dapat dilihat dari program pengurus yang bukan hanya sekedar menjadikan masjid menjadi tempat sholat tetapi juga menjadikan masjid sebagai tempat pembinaan, kegiatan sosial dan pendidikan yang telah memenuhi standar pembinaan manajemen masjid yang telah diatur dalam Keputusan Direktur Jendral Bimbingan Masyarakat Islam Tahun 2014.

Menurut Keputusan Direktur Jendral Bimbingan Masyarakat Islam Tahun 2014, Ruang Lingkup Standar Pembinaan Manajemen Masjid Meliputi :

a. Standar Masjid di Indonesia berdasarkan tipologi (struktur, sektoral, teritorial, dan sejarah) dan perkembangannya terdiri dari Masjid Negara, Masjid Nasional, Masjid Raya, Masjid Agung, Masjid Besar, Masjid Jami', Masjid Bersejarah, dan Masjid ditempat Publik.

b. Standar Pembinaan Manajemen atau Pengelolaannya ditinjau dari aspek iradah (manajemen), imarah (memak-murkan) dan raiyah (pemeliharaan dan pengadaan fasilitas).

Di kota Bengkulu sendiri, menurut data dari Kemenag Kanwil Bengkulu(http://bengkulu.kemenag.go.id) terdapat 460 masjid dan 70 musholla. Dari masjid-masjid tersebut ada beberapa masjid yang aktif dalam kegiatan-kegiatan pember-dayaan, diantaranya adalah Masjid Besar Baitul Atieq yang merupakan masjid bertipologi Masjid Jami' yang berlokasi di
Jl. Meranti Raya Kelurahan Sawah Lebar Kota Bengkulu.

Dari hasil observasi yang di lakukan pada tanggal 6 januari 2020, Masjid Besar Baitul Atieq Merupakan masjid yang berhasil dalam membina dan memakmurkan masjid. Tolak ukur keberhasilan Masjid Besar Baitul Atieq dalam memakmurkan masjid yaitu telah sesuai dengan Keputusan Direktur Jendral Bimbingan Masyarakat Islam Tahun 2014 tentang Standar Pembinaan Manajemen Masjid yaitu Masjid Besar Baitul Atieq bukan hanya digunakan sebagai tempat ibadah sholat, namun juga sebagai tempat memberdayakan masyarakat dengan diadakannya majelis-majelis ilmu dan kegiatan sosial ekonomi yang rutin dilaksanakan seperti kajian rutin Majelis Pengajian Belajar Baca Al-Qur'an setiap hari setelah Sholat Magrib, Madrasah Diniyah Awaliyah yang dilaksanakan Senin hingga Jum'at setelah Sholat Ashar, Pengajian Subuh yang dilaksanakan setiap hari setelah Sholat Subuh, santunan rutin untuk jamaah yang membutuhkan, program pemberdayaan ekonomi jamaah serta pelayanan-pelayanan yang berkaitan dengan kebutuhan jamaah dalam kehidupan seharihari.

Selain itu, peneliti juga melakukan perbandingan dengan beberapa masjid dengan tipologi yang sama dalam melaksanakan program pembinaan atau pemberdayaan yaitu Masjid Al-Hikmah dengan program rutin pengajian subuh dua kali sebulan, Masjid Al- Musyawarah dengan dengan program rutin TPQ setiap Senin hingga Jum'at setelah Ashar, Masjid Al-Azhar dengan program rutin Pengajian 
Subuh setiap Jum'at Pagi, Masjid AlMuslimun dengan program rutin pengajian subuh setiap minggu pagi dan Masjid AlIqra' dengan program rutin pengajian AlQur'an setiap Jum'at malam setelah Isya. Dari hasil observasi tersebut dapat disimpulkan bahwa tidak semua masjid berfungsi sebagai tempat pembinaa dan peberdayaan jamaah.

\section{METODE}

Penelitian berlangsung di Masjid Besar Baitul Atieq yang terletak di Kelurahan Sawah Lebar Kota Bengkulu. Penelitian ini menggunakan metode penelitian kualitatif. Dalam menggali informasi dan mendapatkan data-data peneliti menunjuk empat informan penelitian yang dapat merepresentatifkan hal-hal yang diteliti yaitu: Ir. Suryadi Usman selaku ketua BKM Masjid Besar Baitul Atieq, Rahmaini, S.P selaku ketua majelis taklim ibu-ibu Masjid Besar Baitul Atieq, Ramli Jambak dan Aditya Sultoni selaku jamaah aktif Masjid Besar Baitul Atieq.

Penelitian peneliti menggunakan tiga Teknik pengumpulan data yaitu: wawancara, observasi dan dokumentasi. selain itu, penelitian ini menempatkan peneliti sebagai instrument kunci penelitian. Untuk melakukan uji validasi atau uji keabsahan data, peneliti menggunakan teknik trianggulasi yaitu trianggulasi waktu, trianggulasi subjek, dan trianggulasi teknik.

\section{HASIL DAN PEMBAHASAN}

Kondisi daerah kawasan Sawah Lebar Kota Bengkulu pada tahun 1968 masih daerah hutan, semak, perkebunan dan persawahan di bagian Sawah Lebar ujung, masyarakat yang tinggal dikawasan ini hanya baru beberapa keluarga, untuk sholat jum'at dan sholat lima waktu masyarakat masih ke daerah Padang Jati maka atas inisiatif Bapak Sa'ban, Zikri, Malik, Muhi dan A Reli maka didirikanlah masjid dan diberi nama Masjid Baitul Atiq yang berarti Rumah Tua, yang pada saat itu masih masjid rumah panggung tiang kayu. Masjid Besar Baitul Atieq didirikan pada tanggal 13 juli 1968, mengalami perkembangan demi perkembangan hingga dapat secara perlahan-lahan merenovasi masjid menjadi permanen hingga saat ini dan menjadi masjid yang berhasil dalam melakukan pembinaan dan pemberdayaan umat atau masyarakat.

Menurut Ade Irwan dan Dedi Herlinda (2018:84) menyatakan bahwa "Konsep pemberdayaan diartikan sebagai proses melepaskan situasi atau keadaan ketidakmampuan, ketidakberdayaan, kehilangan, ketersisihkan, dan hal-hal yang berkaitan dengan kelemahan."

Sedangkan menurut Zulfa (dalam Ade Irwan dan Dedi Herlinda, 2018:84) "Pemberdayaan adalah suatu cara dimana rakyat, organisasi, dan komunitas diarahkan agar mampu menguasi kehidupannya."

Dari pendapat tersebut dapat diartikan bahwa pemberdayaan masyarakat dapat dilakukan dimana saja, 
oleh siapa saja dan kapan saja. Salah satunya yaitu pemberdayaan yang dilaksanakan dimasjid. Pemberdayaan masyarakat berbasis masjid dapat diartikan bahwa masjid bukan hanya berfungsi sebagai tempat peribadatan saja namun sebagai tempat pembelajaran dan peningkatan keterampilan.

Menurut Muhammad Qodaruddin, dkk (2016:224) "Masjid dapat digunakan sebagai tempat pelaksanaan berbagai kegiatan, yakni pembinaan kemampuan membaca dan menghafal Al-qur'an, Lembaga Amil Zakat, lembaga penengah sengketa, lembaga solidaritas, bantuan kemanusiaan, lembaga ekonomi, dan lembaga lainnya."

Di Masjid Besar Baitul Atieq sendiri memiliki program-program pemberdayaan dan pembinaan masyarakat dalam beberapa bidang yaitu

\section{a) Pemberdayaan \\ Bidang Pendidikan dan Dakwah}

Program-program

pemberdaya-an di Masjid Besar Baitul Atieq dalam bidang pendidikan dan dakwah yaitu Pengajian Subuh, Majelis Belajar Baca Al-Qur'an, MDTA dan Kajian Majelis Taklim Ibu-Ibu.

1) Pengajian subuh dilaksanakan setiap hari setelah sholat subuh dengan materi yang sudah tejadwal, yaitu Senin materi AlIslam, Selasa materi AlMaatsurat, Rabu materi Tahsin Al-Qur'an, Kamis materi Fiqih Kontemporer, Jum'at Fiqih Sunnah, Sabtu materi terjemahan tafsir Al-Qur'an, Minggu materi Tassawuf.

2) Majelis Belajar Baca Al-Qur'an dilaksanakan setiap hari setelah magrib dengan pengajar Ustadz Asri Damsi.

3) MDTA daksanakan setiap hari senin hingga Jum'at setelah ashar, dengan peserta yaitu anakanak dan tenaga pengajar empat orang.

4) Majelis Taklim Ibu-Ibu rutin setiap satu bulan sekali dengan materi-materi yang telah dirancang bersaama-sama. Untuk pengisi acara merupakan ustad atau pemateri diluar lingkungan Masjid Besar Baitul Atieq.

\section{a) Pemberdayaan Bidang Ekonomi}

Pemberdayaan dibidang ekonomi yaitu pemberian talangan dana untuk masyarakat disekitaran masjid yang memiliki usaha dengan menggandeng Yayasan Ma'had Rabbani untuk memberikan talangan dana untuk masyarakat disekitar masjid yaitu 10 pedangang dengan masing-masing pedangan medapatkan 2 juta rupiah.

Penerima bantuan talangan dana yaitu kepada bapak Yon Edwar penjual lontong, bapak Neko Putra warung manisan, bapak Syarkawi penjual cendol keliling, bapak Hari Siswoyo penjual Es Krim, ibu Meli Hartati penjual kue keliling, ibu Endang Agustian penjual Pecel Lele, ibu Iyeh penjual Es Kelapa Muda, bapak Indra Witi Hardi bengkel 
tampal ban, bapak Antomi usaha cuci motor, bapak purnawarman penjual lontong.

talangan dana tesebut merupakan pinjaman modal tanpa bunga yang merupakan hasil kerja sama antara pengurus Masjid Besar Baitul Atieq dengan Yayasan Ma'had Rabbani.

\section{b) Pemberdayaan Bidang Sosial}

Pemberdayaan dibidang sosial yaitu memberikan santunan dari beberapa jamaah ke jamaah sekitar masjid yang kurang mampu yang dilaksanakan menjelang ramadhan, pemberdayaan kepada fakir, miskin dan yatim yaitu pengurus masjid bekerja sama dengan RT RW setempat untuk melakukan pendataan jamah yang berhak mendapatkan santunan berupa peralatan sekolah, santunan kepada jamaah kurang mampu dan kepada jamaah yang sedang sakit.

Selain itu, Masjid Besar Baitul Atieq rutin memperingati Hari Besar Islam yang diisi dengan pengajian-pengajian dan mendatangkan ustadz dari luar lingkungan Masjid Besar Baitul Atieq untuk menambah wawasan jamaah.

Menurut Muhammad Qodaruddin, dkk (2016:226) "Upaya meningkatkan kualitas hidup masyarakat dapat dilakukan melalui peningkatan Sumber Daya Manusia (SDM) dengan melakukan kegiatan ekonomi dan sosial berbasis masjid."

Dari pendapat diatas peneliti menyimpulkan bahwa masjid dapat melakukan kegiatan-kegiatan dalam meningkatkan SDM jamaah melalui kegiatan-kegiatan masjid. Oleh karena itu, penting untuk membuat kegiatankegiatan yang sesuai dengan kebutuhan jamaah.

Di Masjid Besar Baitul Atieq sendiri, program-program yang dilaksanakan dibuat bersama-sama antara pengurus masjid, para alim ulama dan jamaah serta disesuaikan dengan kebutuhan jamaah sehingga jamaah antusias dalam mengikuti program-program di masjid.

\section{KESIMPULAN}

Dari pembahasan yang telah dipaparkan diatas mengenai progam pemberdayaan masyarakat berbasis masjid pada Masjid Besar Baitul Atieq Sawah Lebar Kota Bengkulu, dapat disimpulkan bahwa masjid bukan hanya dapat difungsikan sebagai tampat peribadatan saja, namun masjid memiliki peran strategis dalam melakukan pemberdayaan dan pembinaan kepada jamaah atau masyarakat disekitar masjid. Program-program pemberdayaan masyarakat di Masjid Besar Baitul Atieq, meliputi bidang pendidikan dan dakwah, meliputi pengajian rutin subuh, majelis belajar baca Al-Qur'an, MDTA dan Majelis Taklim, bidang ekonomi yaitu memberikan talangan dana kepada jamaah yang memiliki usaha dan bidang sosial yaitu memberikan santunan kepada jamaah yang membutuhkan serta program-program lain yang bersifat Isendental. 


\section{REFERENSI}

Kualitatif (Analisis Data). Jakarta : Rajawali Pers

Herdiyansyah, Harris. (2012). Penelitian Kualitatif untuk Ilmu-Ilmu Sosial. Jakarta Selatan:Salemba Humanika.

http://bengkulu.kemenag.go.id diakses pada 16 Juli 2020 pukul 20.15 wib

http://globalreligiousfutures.org diakses pada 16 Juli 2020 pukul 20.20 wib

Iwan, Ade. R. dan Herdiana Dedi. (2018) Optimalisasi Pemberdayaan Masyarakat Berbasis Masjid. Ilmu Dakwah: Academic Journal for Homiletic Studies. 12 (1) hlm.82-98.

Iskandar. (2008). Metodologi penelitian Kualitatif. Yogyakarta: Penerbit Ardi.

Keputusan Direktur Jendral Bimbingan Masyarakat Islam Tahun 2014 tentang Standar Pembinaan Manajemen Masjid.

Qodaruddin, Muhammad, dkk. (2016) Peran Dakwah Masjid Dalam Meningkatkan Kualitas Hidup Masyarakat. Ilmu Dakwah: Journal for Homiletic Studies. 10 (2) hlm. 222-239.

Rukaman, Nana. (2002). Masjid dan Dakwah. Jakarta: Al-mawardi Prima

Sugiyono. (2010). Metode Penelitian Kualitatif, Kuantitatif dan R\&D. bandung: PT Alfabeta. 